\title{
Pengaruh Model Pembelajaran SFAE Berbasis Tri Kaya Parisudha Terhadap Hasil Belajar Matematika Siswa
}

\author{
Luh Sri Widiasih ${ }^{*}$, I Made Suarjana², Ndara Tanggu Renda3
}

1,2,3Pendidikan Guru Sekolah Dasar, Fakultas Ilmu Pendidikan, Universitas Pendidikan Ganesha

\author{
A R T I C L E I N F O \\ Article history: \\ Received 10 February \\ 2019 \\ Received in revised form \\ 09 March 2019 \\ Accepted 15 April 2019 \\ Available online 25 May \\ 2019 \\ Kata Kunci: \\ student facilitator and \\ explaining tri kaya \\ parisudha, hasil belajar \\ matematika \\ Keywords: \\ student facilitator and \\ explaining, tri kaya \\ parisudha, mathematics \\ achievement
}

\begin{abstract}
A B S T R A K
Penelitian ini bertujuan untuk mengetahui perbedaan hasil belajar matematika antara kelompok siswa yang mengikuti pembelajaran dengan model pembelajaran Student Facilitator And Explaining (SFAE) berbasis Tri Kaya Parisudha dengan kelompok siswa yang mengikuti pembelajaran konvensional pada siswa kelas III SD Semester Genap Gugus IV Kecamatan Gerokgak Kabupaten Buleleng Tahun Pelajaran 2017/2018. Desain penelitian ini adalah penelitian eksperimen semu (quasi eksperimen) dengan rancangan posttest only control grup design. Populasi penelitian ini adalah seluruh siswa kelas III SD Gugus IV Kecamatan Gerokgak yang berjumlah 186 orang. Sampel penelitian ini adalah siswa kelas III SD Negeri 2 Gerokgak dengan jumlah 34 siswa sebagai kelompok eksperimen dan siswa kelas III SD Negeri 3 Gerokgak dengan jumlah 40 siswa sebagai kelompok kontrol. Pengumpulan data dilakukan dengan menggunakan metode tes dalam bentuk tes objektif. Data yang diperoleh dianalisis menggunakan uji-t. Hasil analisis diperoleh thitung $=7,38$ sedangkan pada taraf signifikan 55 dan $\mathrm{dk}=72$ diperoleh nilait tabel $=1,99$ sehingga thitung $=7,38$ $>$ ttabel $=1,99$. Berdasarkan kriteria pengujian, maka $\mathrm{H}_{0}$ ditolak dan $\mathrm{Ha}$
\end{abstract} diterima. Adapun nilai rata-rata skor hasil belajar matematika pada kelompok eksperimen adalah 14,71, sedangkanr ata-rata pada kelompok kontrol adalah 11,2. Berdasarkan hasil tersebut dapat disimpulkan bahwa terdapat pengaruh yang signifikan pada hasil belajar antara siswa yang dibelajarkan dengan model pembelajaran Studen Facilitator and Explaining dan kelompok siswa yang dibelajarkan dengan pembelajaran konvensional pada siswa kelas III semester II di Gugus IV Kecamatan Gerokgak tahun pelajaran 2017/2018.

\section{A B S T R A C T}

This study aims to determine the difference of the students' mathematics achievementbetween the students who are taught with student facilitator and explaining (SFAE) learning model based on Tri Kaya Parisudhaand those are taught with conventional learning in third-grade students of Gugus IV Gerokgak, Bulelengregency in academic year 2017/2018. The design of this study was quasi experimentalwith posttest only control group design. The population of this study was all the thirdgrade students of Gugus IV, Gerokgak which were 186 students. The sample of this study was the third-grade students of SD Negeri 2 Gerokgak with 34 students as experimental group and the thirdgrade students of SD Negeri 3 Gerokgak with 40 students as control group. Data collection was obtained by using objective test method. The data were analyzed by using T-test. The result of this study wasthitung $=7,38$ with the significant level 55 and $d k=72$ with tabel $=1.99$ so thitung $=7,38>t_{\text {tabel }}=$ 1,99. Based on the test criteria, then $\mathrm{HO}$ was rejected and Ha was accepted. The average score of mathematics learning achievement in the experimental group was 14.71, while the average score for the control group was 11.2. Based on the results above, it can be concluded that there was a significant effect toward the students' mathematics achievementbetween the students who are taught with Student Facilitator and Explaining (SFAE) learning model based on Tri Kaya Parisudha and those are taught with conventional learning in third grade students of Gugus IV Gerokgak, Bulelengregency in academic year 2017/2018.

Copyright @ Universitas Pendidikan Ganesha. All rights reserved. 


\section{Pendahuluan}

Pendidikan merupakan salah satu usaha pembangunan jangka panjang yang sangat penting untuk meningkatkan kualitas sumber daya manusia (SDM). Melalui proses pendidikan manusia dapat membangun kebudayaan dan peradaban yang diharapkan mampu bersaing di era globalisasi. Itulah sebabnya hampir semua Negara menempatkan pendidikan sebagai pilar utama pencetak manusia berkualitas. Sebagaimana tercantum dalam pembukaan Undang-Undang Dasar 1945 alinea IV yang sangat ditegaskan bahwa salah satu tujuan bangsa Indonesia adalah mencerdaskan kehidupan bangsa. Selanjutnya disusunlah UU RIpada Bab 1, Pasal 1, No. 20 Tahun 2003 yang menyatakan bahwa, Pendidikan adalah usaha sadar dan terencana untuk mewujudkan suasana belajar dan proses pembelajaran agar peserta didik secara aktif mengembangkan potensi dirinya untuk memiliki kekuatan spiritual keagamaan, pengendalian diri, kepribadian, kecerdasan, akhlak mulia, serta keterampilan yang diperlukan dirinya, masyarakat, bangsa dan negara. Pendidikan merupakan salah satu bentuk upaya untuk meningkatkan kualitas sumber daya manusia. Pendidikan dalam arti usaha sadar dan terencana mewujudkan proses belajar sepanjang hayat, menyentuh semua sendi lapisan masyarakat terhadap setiap perkembangan dunia pendidikan terutama pendidikan dalam bidang kejuruan (Ariska, 2017). Badan Standar Nasional Pendidikan (2006 dalam Seandanu, 2017) mengemukakan bahwa tujuan pendidikan dasar adalah meletakkan dasar kecerdasan, pengetahuan, kepribadian, akhlak mulia, serta keterampilan untuk hidup mandiri dan mengikuti pendidikan lebih lanjut. Dalam hal ini berarti proses pendidikan berujung pada pembentukan sikap, pengembangan kecerdasan atau intelektual.

Secara jelas tujuan pendidikan nasional yang bersumber dari sistem nilai pancasila dirumuskan dalam Undang-Undang No.20 Tahun 2003, Pasal 3, Pendidikan nasional berfungsi mengembangkan kemampuan dan membentuk watak serta peradaban bangsa yang bermartabat dalam rangka mencerdaskan kehidupan bangsa, bertujuan untuk berkembangnya potensi peserta didik agar menjadi Marusia yang beriman dan bertakwa kepada Tuhan Yang Maha Esa, berakhlak mulia, sehat, berilmu, cakap, kreatif, mandiri, dan menjadi warga negara yang demokratis serta bertanggung jawab.

Untuk mencapai tujuan pendidikan pemerintah telah melakukan berbagai upaya yang salah satunya melaksanakan kurikulum di berbagai jenjang pendidikan termasuk pendidikan dasar khususnya di SD. Menurut Sailor dan Alexander (dalam Trianto, 2010) kurikulum adalah segala usaha dalam rangka mempengaruhi anak untuk belajar, baik di dalam ruang kelas maupun di luar sekolah. Sehingga dapat dikatakan untuk mencapai tujuan pendidikandilaksanakan pembelajaran di sekolah melalui matapelajaran mata-pelajaran sebagaimana ditetapkan dalam pasal 37 ayat 1 UU No. 20 Tahun 2003. Yang salah satunya adalah pembelajaran matematika. Matematika adalah salah satu bidang studi yang dapat meningkatkan kemampuan berpikir, memberikan kontribusi dalam penyelesaian masalah sehari-hari serta dalam dunia kerja, dan untuk mendukung perkembangan ilmu pengetahuan. (Dharma, 2016) menyatakan, pelajaran matematika khususnya di sekolah dasar diajarkan dengan tujuan memberikan konsep awal kepada siswa untuk mempelajari matematika pada jenjang yang lebih tinggi. (Susanto, 2015: 195) menyatakan bahwa matematika merupakan salah satu bidang studi yang berguna dan membantu dalam menyelesaikan masalah dalam kehidupan sehari-hari yang berhubungan dengan hitungmenghitung atau yang berurusan dengan angka-angka dan berbagai macam masalah, yang memerlukan suatu keterampilan dan kemampuan untuk memecahkanya.

Maka untuk mencapai tujuan pembelajaran mata pelajaran matematika tersebut, seorang guru memerlukan suatu model, strategi, dan metode Pembelajaran yang dapat menciptakan kondisi dan situasi pembelajaran menjadi aktif serta meningkatkan hasil belajar siswa.

Namun, pada kenyataannya ketika dilakukan wawancara, observasi, dan studi dokumen pada tanggal 28 Desember 2017 pada guru-guru bidang studi matematika di Gugus IV Kecamatan Gerokgak Kabupaten Buleleng.

Berdasarkan hasil wawancara tentang permasalahan yang dihadapi dalam pembelajaran matematika yaitu, 1) waktu yang digunakan tidak cukup dalam menyampaikan materi yang banyak, 2) siswa malu bertanya dan mengemukan pendapatnya, sehingga pembelajaran menjadi pasif, 3) penggunaan media yang kurang.

Untuk memperkuat hasil wawancara kemudian dilakukan observasi pada tanggal 29 Desember 2017 pada guru-guru bidang studi matematika di Gugus IV Kecamatan Gerokgak Kabupaten Buleleng. Kenyataannya, 1) guru lebih banyak menggunakan metode ceramah, 2) setelah menjelaskan guru langsung memberikan soal-soal latihan, 3) pembelajaran masih individual, sangat abstrak dan teoritis, sehingga siswa menjadi pasif dalam pembelajaran, 4) interaksi antara siswa kurang, 5) guru hanya mengandalkan buku paket saja dalam proses tanpa memanfaatkan sumber lain, dan 6) guru kurang memanfaatkan media dalam proses pembelajaran. 
Berdasarkan hasil wawancara dan observasi dapat dilihat bahwa guru masih menerapkan pembelajaran konvensional yang menganggap siswa hanya sebagai objek bukan subjek didalam proses pembelajarandi SD. Ini mencerminkan bahwa guru masih mendominasi pembelajaran dan siswa hanya menerima ilmu yang diberikan guru tanpa mampu menggali sendiri pengetahuannya.

Untuk melengkapi hasil wawancara dan observasi dilakukan studi dokumen dengan nilai UTS mata pelajaran matematika siswa di Gugus IV Kecamatan Gerokgak yang terdiri dari 6 sekolah. Diketahui bahwa nilai rata-rata hasil belajar matematika siswa kelas III Gugus IV Kecamatan Gerokgak berkisar antara 71,22 sampai 72,64. Jika dikonversikan ke tabel konversi tingkat pencapaian skala lima (Agung, 2014: 451), nilai rata-rata tersebut berada pada kategori sedang.

Melihat permasalahan tersebut, diperlukan suatu solusi yang dapat menciptakan pembelajaran interaktif, memfasilitasi siswa dalam belajar dan dapat mengubah proses pembelajaran yang awalnya berpusat pada guru menjadi belajar yang berpusat pada siswa. Untuk itu, guru harus mampu menggunakan model pembelajaran dengan tepat untuk meningkatkan hasil belajar matematika siswa. Salah satu model pembelajaran yang efektif untuk mengatasi masalah-masalah tersebut adalah dengan penerapan model pembelajaran Student Facilitator and Explaining (SFAE) model ini akan dapat menjadi salah satu solusi untuk membantu memenuhi kebutuhan peserta didik, meningkatkan hasil belajar matematika siswa. Suyanto dalam (Fauzi, Riski, 2016:3) Model pembelajarn Student Facilitator and Explaining merupakan suatu model yang memberikan kesempatan kepada siswa untuk mempresentasikan idea atau pendapat pada siswa lainnya. Belajar dengan SFAE menunjukkan bahwa peserta didik akan lebih cepat memahami apa yang diajarkan oleh temannya daripada yang diajarkan oleh gurunya.

Model pembelajaran kooperatif tipe student facilitator and explaining menekankan siswa untuk lebih berpartisipasi aktif dalam proses pembelajaran dengan memberikan kesempatan siswa yang ditunjuk sebagai tutor sebaya untuk menjelaskan materi pelajaran yang telah dijelaskan guru kepada siswa lainnya. Sebelum proses pembelajaran dimulai, guru menjelaskan secara singkat bentuk dari model pembelajaran kooperatif tipe student facilitator and explaining terlebih dahulu. Guru mengelompokkan siswa menjadi beberapa kelompok yang terdiri dari 4-6 orang secara heterogen baik dilihat dari kemampuan maupun jenis kelamin siswa, guru menunjuk satu orang siswa dari setiap kelompok untuk dijadikan sebagai facilitator (tutor) dan setiap facilitator diberi arahan, guru menyampaikan dan mendemonstrasikan (menyajika(Yanto, 2018)n) materi pembelajaran, guru memberikan kesempatan siswa yang ditunjuk sebagai tutor sebaya untuk menjelaskan kepada siswa lainnya, guru menyimpulkan ide atau pendapat dari siswa, guru menerangkan semua materi yang disajikan sebagai kesimpulan, dan kemudian guru menutup pelajaran seperti proses yang seharusnya (Yanto, 2018).

Model pembelajaran SFAE juga harus dipadukan dengan Tri Kaya Parisudha, Tri Kaya Parisudha menurut (Sukadi, Dkk, 2007:134) Tri Kaya Parisudha (tiga hal yang disucikan), yaitu "pengendalian pikiran dengan cara berpikir yang benar (manacika), pengendalian perkataan dengan dengan cara berkata yang benar (wacika), dan pengendalian perbuatan dengan cara berbuat yang benar(kayika)". Tri Kaya Parisudha merupakan suatu ajaran yang menjadi tuntunan bagi umat hindu yaitu tuntunan dalam berkata, berpikir dan berbuat. Menyatukan aspek berkata, berpikir dan berbuat merupakan satu kesatuan yang utuh dalam berbuat dan berperilaku dalam bermasyarakat. Penekanan konsep tersebut dalam pembelajaran matematika akan sangat membantu siswa untuk mengembangkan pengetahuan, pemahan dan keterampilan untuk menyelesaikan masalah-masalah yang terdapat dalam pembelajaran matematika. Serta konsep Tri Kaya Parisudha dapat menyadarkan siswa untuk berkata, berpikir, dan berbuat yang baik bukan hanya dilingkungan sekolah saja, akan tetapi harus diterapkan dalam kehidupan sehari-hari.

Tujuan penelitian ini adalah, Untuk mengetahui perbedaan hasil belajar matematika antara kelompok siswa yang mengikuti pembelajaran dengan model pembelajaran SFAE berbasis Tri Kaya Parisudha dengan kelompok siswa yang mengikuti pembelajaran konvensional pada siswa kelas III SD Gugus IV Kecamatan Gerokgak Tahun Pelajaran 2017/2018.

\section{Metode}

Jenis penelitian ini adalah eksperimen semu (quasi eksperimen) desain eksperimen yang digunakan adalah only control grup design. Dalam desain tersebut, terdapat dua kelompok yang masing-masing dipilih secara acak. Dengan kelompok pertama diberikan perlakuan (treatment) sedangkan kelompok kedua tidak diberikan peralakuan (treatment) kelompok yang diberikan perlakuan disebut kelas eksperimen dan kelompok yang tidak diberikan perlakuan disebut kelas kontrol. Kedua kelas baik kelas ekseperimen maupun kelas kontrol kemudian dilakukan pengukuran hasil belajar untuk melihat berbedaan hasil belajar terhadap perbedaan perlakuan tersebut. Penelitian ini menggunakann Non equevalent Posttest Only Control Grup Design.

Populasi dalam penelitian ini adalah seluruh siswa kelas III SD Gugus IV Kecamatan Gerokgak tahun pelajaran 2017/2018 yang terdiri dari SD Negeri 1 Gerokgak, SD Negeri 2 Gerokgak, SD Negeri 3 
Gerokgak, SD Negeri 4 Gerokgak, SD Negeri 2 Sanggalangit, dan SD Negeri 3 Sanggalangit. Yang berjumlah 6 kelas dan dalam 1 SD terdiri 1 kelas sehingga secara keseluruhan berjumlah 6 kelas, dengan jumlah siswa sebanyak 186 siswa. Sampel pada penelitian ini menggunakan teknik random sampling.

Prosedur penelitian yang akan dilaksanakan pada penelitian ini adalah sebagai berikut. 1) menentukan sekolah yang digunakan sebagai tempat penelitian. 2) mengadakan wawancara, observasi dan studi dokumen di seluruh kelas III di SD Gugus IV Kecamatan Gerokgak, Kabupaten Buleleng,3) mengadakan pengundian sampel 4) meminta izin kepada kepala sekolah 5) Menyiapkan materi 6) menyusun dan merancang perangkat pembelajaran, seperti rencana pelaksanaan pembelajaran (RPP). tahap Pelaksanaan 1). Memberikan perlakuan pembelajaran kepada kelompok eksperimen dengan model pembelajaran Student Facilitattor and Explaining dan kelompok kontrol dengan pembelajaran konvensional 2) Memberikan perlakuan pada kelompok eksperimen dan kelompok kontrol sebanyak 7 kali pertemuan 3) Mengadakan post-test (tes akhir).

Teknik analisis data yang digunakan dalam penelitian ini, yaitu analisis statistik deskriptif dan analisis statistik inferinsial. Analisis deskriptif dilakukan untuk mengetahui profil masing-masing variabel dalam wujud deskriptif tentang pengaruh model pembelajaran SFAE berbasis Tri Kaya Parisudha terhadap hasil belajar matematika. Analisis deskriptif menampilkan rata-rata, standar deviasi, modus, median, nilai minimum, nilai maksimum, dan jumlah data dari setiap variabel yang diteliti. Selain mendapatkan harga-harga tersebut, ditampilkan juga grafik polygon untuk setiap variabel penelitian. Analisis inferensial digunakan untuk menguji hipotesis penelitian. Sebelum melakukan analisis data, maka data yang diperoleh diuji terlebih dahulu normalitas distribusi dan homogenitas variansnya. Untuk menguji hipotesis digunakan independent sample t-test dengan rumus polled varians (Agung, 2014: 34).

\section{Hasil dan Pembahasan}

Data hasil belajar matematika yang diperoleh melalui post-test terhadap kelompok eksperimen dan kelompok kontrol diperoleh skor seperti pada tabel 1 berikut.

Tabel 1. Rangkuman hasil perhitungan kelompok eksperimen dan kelompok

\begin{tabular}{lcc}
\hline \multicolumn{1}{c}{ Statistik } & Kelompok Eksperimen & Kelompok Kontrol \\
\hline Mean & 14,71 & 11,2 \\
Median & 15 & 11 \\
Modus & 16 & 9 \\
Varians & 3,60 & 4,49 \\
Standar Deviasi & 1,90 & 2,12 \\
Skor minimum & 11 & 8 \\
Skor maxsimum & 18 & 15 \\
\hline
\end{tabular}

Mean, median, modus hasil belajar matematika selanjutnya disajikan ke dalam kurva polygon. Tujuan penyajian data ini adalah untuk menafsirkan sebaran data hasil belajar matematika siswa. Hubungan antara mean (M), median (Me), dan modus (Mo) dapat digunakan untuk menentukan kemiringan kurva polygon distribusi frekuensi

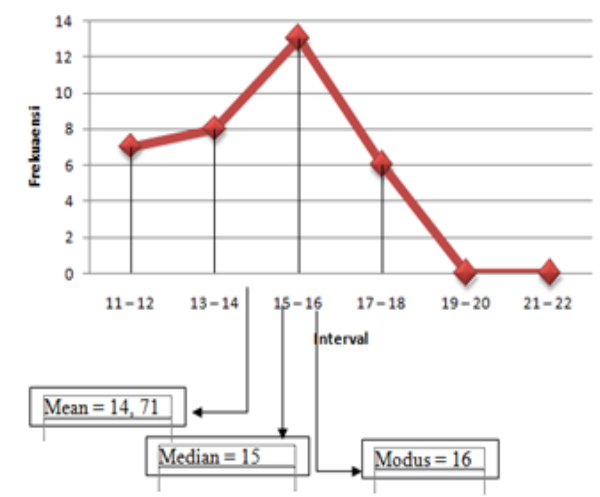

Gambar 1. Kurva Poligon post-test kelompok eksperimen

Berdasarkan nilai titik tengah dan frekuensi masing-masing kelas interval serta hasil perhitungan tabel distribusi frekuensi didapatkan bahwa mean lebih kecil daripada modus dan median lebih besar dari mean $(14,71<15<16)$. Sehingga Rata-rata hasil belajar Matematika siswa pada kelompok yang 
dibelajarkan dengan model pembelajaran Student Facilitator And Explaining (SFAE) Berbasis Tri Kaya Parisudha termasuk kategori tinggi.

Mean, median, dan modus dari hasil belajar siswa pada kelompok yang dibelajarkan dengan pembelajaran konvensional selanjutnya disajikan ke dalam kurva poligon. Tujuan penyajian data ini adalah untuk menafsirkan sebaran data skor hasil belajar siswa pada kelompok yang dibelajarkan dengan pembelajaran konvensional. Hubungan antara mean (M), median (Md), dan modus (Mo) dapat digunakan untuk menentukan kemiringan kurva poligon distribusi frekuensi.

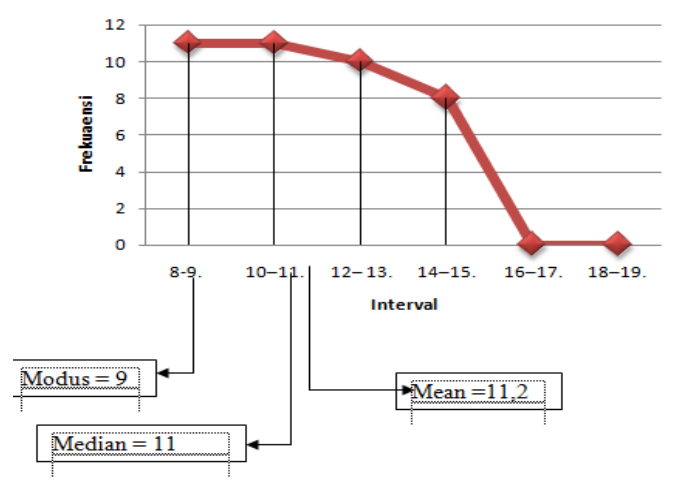

Gambar 2. Kurva Poligon Kelompok Konvensional

Berdasarkan hasil tersebut dapat diketahui bahwa mean lebih besar dari median dan median lebih besar dari modus $(9<11<11,2)$. Sehingga Rata-rata hasil belajar Matematika pada kelompok yang dibelajarkan dengan pembelajaran konvensional termasuk kategori sedang

Teknik analisis data yang digunakan untuk menguji hipotesis adalah uji-t . Data yang digunakan dalam uji ini adalah data hasil belajar matematika siswa. Sebelum melakukan pengujian terhadap hipotesis penelitian, maka terlebih dahulu dilakukan pengujian prasyarat analisis. Uji prasyarat analisis meliputi uji normalitas data dan uji homogenitas varians yang dikenakan pada kedua kelompok. Berikut ini deskripsi hasil pengujian normalitas dan homogenitas terhadap data hasil belajar matematika siswa

Hasil analisis data post-test kelompok yang dibelajarkan dengan model pembelajaran Student Facilitator And Explaining (SFAE) Berbasis Tri Kaya Parisudhadengan menggunakan rumus Chi-kuadrat, diperoleh $\chi^{2}$ hitung adalah 4,845 dan $\chi^{2}$ tabel dengan taraf signifikansi dan $\mathrm{dk}=6-1=5$ adalah 11,070. Dengan demikian, $\chi^{2}$ hitung $<\chi^{2}$ tabel $(4,845<11,070)$ sehingga data post-test hasil belajar kelompok yang dibelajarkan dengan model pembelajaran Student Facilitator And Explaining (SFAE) Berbasis Tri Kaya Parisudhaberdistribusi normal.

Adapun hasil analisis data post-test kelompok yang dibelajarkan dengan pembelajaran konvensional dengan menggunakan rumus Chi-kuadrat, diperoleh $\chi^{2}$ hitung adalah 6,705 dan $\chi^{2}$ tabel dengan taraf signifikansi $5 \%$ dan $\mathrm{db}=6-1=5$ adalah 11,070 . Dengan demikian, $\chi^{2}$ hitung $<\chi^{2}$ tabel $(6,705<11,070)$ sehingga data post-test kelompok yang dibelajarkan dengan pembelajaran konvensional berdistribusi normal.

Uji homogenitas varians antar kelompok eksperimen dan kontrol menggunakan uji F. Berdasarkan perhitungan uji homogenitas Hasil analisis, diperoleh $\mathrm{F}_{\text {hitung }}=2,00$ dan $\mathrm{F}_{\text {tabel }}$ dengan taraf signifikansi 5\% $(0,05)$ dengan db pembilang $34-1=33$ dan db penyebut 40-1=39 adalah 3,97. Dengan demikian, $F_{\text {hitung }}=$ $1,85<\mathrm{F}_{\text {tabel }}=3,97$ maka varians homogen Untuk menguji hipotesis digunakan analisis independent sample t-test

polled varians. Diketahui $\overline{X_{1}}=14,71, \overline{X_{2}}=11,2, S_{1}^{2}=60,42, S_{2}^{2}=32,67, n_{1}=34, n_{2}=40$. Hasil perhitungan uji-t disajikan pada Tabel 2 berikut ini.

Tabel 2. Rangkuman Hasil Uji-t

\begin{tabular}{lccccccc}
\hline \multicolumn{1}{c}{ Sampel Penelitian } & $\begin{array}{c}\text { Jumlah } \\
\text { siswa }\end{array}$ & Meañ & $\begin{array}{c}\text { Standar } \\
\text { Deviasi }\end{array}$ & Varian & Db & $\mathrm{t}_{\text {hitung }}$ & $\mathrm{t}_{\text {tabel }}$ \\
\hline Kelompok Eksperimen & 34 & 14,71 & 1,90 & 3,60 & & 7,38 & 1,99 \\
Kelompok control & 40 & 11,02 & 2,12 & 4,49 & 72 & \\
\hline
\end{tabular}

Berdasarkan hasil penelitian pada kelompok yang dibelajarkan dengan model pembelajaran Student Facilitator And Explaining (SFAE) Berbasis Tri Kaya Parisudha dan kelompok yang dibelajarkan dengan pembelajaran konvensional setelah diberikan post test, diperoleh hasil bahwa rata-rata post test 
hasil belajar matematika yang dicapai siswa pada kelompok yang dibelajarkan meggunakan model pembelajaran Student Facilitator And Explaining (SFAE) Berbasis Tri Kaya Parisudha adalah 14,71 sedangkan rata-rata post test hasil belajar matematika yang dicapai siswa pada kelompok yang dibelajarkan meggunakan pembelajaran konvensional adalah 11,2. Dengan demikian, rata-rata post test hasil belajar Matematika pada kelompok siswa yang dibelajarkan meggunakan model pembelajaran Student Facilitator And Explaining (SFAE) Berbasis Tri Kaya Parisudha lebih besar dibandingkan dengan kelompok siswa yang dibelajarkan dengan menggunakan pembelajaran konvensional.

Selain dilihat dari nilai rata-rata tersebut, perbedaan antara kelompok siswa yang dibelajarkan meggunakan model pembelajaran Student Facilitator And Explaining (SFAE) berbasis Tri Kaya Parisudha dengan kelompok siswa yang dibelajarkan dengan menggunakan pembelajaran konvensional juga dapat dilihat berdasarkan hasil analisis uji-t yang diketahui diketahui $t_{\text {hitung }}=7,38$ dan $t_{\text {tabel }}=1,99$ untuk db $=72$ pada taraf signifikansi 5\%. Dari hasil perhitungan tersebut pada taraf signifikansi 5\% diketahui $t_{\text {hitung }}>$ tabel, hal ini berarti hasil penelitian signifikan. Jadi, dapat diketahui bahwa terdapat perbedaan hasil belajar matematika antara kelompok siswa yang dibelajarkan dengan menggunakan model pembelajaran Student Facilitator And Explaining (SFAE) berbasis Tri Kaya Parisudha dan kelompok siswa yang dibelajarkan dengan menggunakan pembelajaran konvensional pada siswa kelas III SD semester genap tahun pelajaran 2017/2018 di Gugus IV Kecamatan Gerokgak.

Perbedaan hasil belajar Matematika yang dibelajarkan dengan menerapkan model pembelajaran Student Facilitator And Explaining (SFAE) berbasis Tri Kaya Parisudha dengan pembelajaran konvensional disebabkan oleh adanya perbedaan sintak masing-masing pembelajaran yaitu sebagai berikut. 1) penyajian kelas, 2) belajar dalaam kelompok, 3) evaluasi, 4) Penghargaan kelompok. Pembelajaran SFAE pada kelompok eksperimen menjadikan siswa lebih aktif ,1) memberikan kesempatan kepada siswa untuk mengemukakan pendapat atau penjelasan yang dipahami ketika proses pembelajaran berlangsung, 2) dengan berbasis Tri Kaya Parisudha jika dalam proses belajar kelompok siswa selalu berkata yang baik, saling memaafkan jika terjadi kesalahan, 3) siswa semangat belajar karena dalam proses pembelajaran selalu menggunakan LKS, dan setiap akhir proses pembelajaran selalu memberikan test evaluasi. Hal tersebut juga sesuai dengan pendapat (Ngalimun, 2014) yang menyatakan bahwa pembelajaran dengan model tersebut dimulai dengan berpikir melalui bahan bacaan (menyimak, mengkritisi, dan mencari solusi), hasil bacaanya dikomunikasikan dengan presentasi, diskusi, dan kemudian membuat laporan hasil presentasi. Salah satu kelebihan model pembelajaran Student Facilitator And Explaining (SFAE) berbasis Tri Kaya Parisudha adalah Melatih siswa untuk menjadi guru karena siswa diberikan kesempatan untuk mengulangi penjelasan guru yang telah dia dengar.

Berbeda halnya dengan pembelajaran konvensional yang cenderung berpusat pada guru. Dalam pembelajaran dengan model konvensional, siswa cenderung menjadi objek belajar, sedangkan guru yang menjadi subjek dengan dominasi ceramah pada setiap pembelajarannya. Adapun langkah-langkah yang temukan dalam pembelajaran model konvensional pada kelas kontrol yaitu 1) dimulai dari pemberian informasi dari guru, 2) tanya jawab, 3) pemberian tugas dan pelaksanaan tugas oleh siswa sampai pada akhirnya guru merasa bahwa apa yang telah diajarkan dapat dimengerti siswa. Keadaan tersebut cenderung membuat siswa menjadi pasif sehingaa menimbulkan kebosanan, kurang menarik minat siswa dalam belajar, yang berdampak pada rendahnya hasil belajar siswa.

Hasil penelitian ini juga didukung oleh beberapa penelitian yang terkait dengan penggunaan model pembelajaran Student Facilitator And Explaining (SFAE) Berbasis Tri Kaya Parisudha. Penelitian yang dilakukan oleh Irmayanti (2017) yang berjudul "Pengaruh Model Pembelajaran Kooperatif TTW berbasis Kearifan Loka Tri Kaya Parisudha terhadap hasil belajar IPA Pada Siswa Kelas V" menyatakan bahwa terdapat perbedan yang signifikan antara siswa yang dibelajarkan dengan model pembelajaran Kooperatif TTW berbasis Kearifan Loka Tri Kaya Parisudha dengan yang mengikuti pembelajaran konvensional.

Selain itu penelitian yang dilakukan oleh (Mudarini, 2017) yang menunjukkan bahwa model pembelajaran Student Facilitator And Explaining (SFAE) dapat meningkatkan hasil belajar IPA siswa. (Santa, Suarjana, Sudatha, 2013) menunjukan bahwa model pembelajaran Student Facilitator And Explaining (SFAE) berpengaruh positif pada prestasi belajar matematika siswa.

\section{Simpulan dan Saran}

Dari Berdasarkan hasil analisis dan pembahasan seperti yang telah diuraikan dapat disimpulkan sebagai berikut. Nilai rata-rata dari masing-masing kelompok. Kelompok eksperimen 14,71 dan kelompok kontrol 11,2. Melalui pengujian hipotesis diperoleh thitung $=7,38$. Berdasrkan taraf signifikansi $5 \%$ dan derajat kebebasan $\mathrm{db}=72$ diperoleh nilai $\mathrm{t}_{\text {tabel }}=1,99$ karena $\mathrm{t}_{\text {hitung }}=7,38$. dan $\mathrm{t}_{\text {tabel }}=1,99$, ini berarti $\mathrm{t}_{\text {hitung }}$ $>$ tabel maka hipotesis nol ditolak dan hipotesis alternatif diterima. Berarti terdapat perbedaan hasil belajar yang signifikan anatar kelompok siswa yang dibelajarkan dengan model pembelajaran kooperatif tipe Student Facilitator And Explaining (SFAE) Berbasis Tri Kaya Parisudha dan kelompok siswa yang dibelajarkan dengan pembelajaran konvensional pada siswa kelas III semester II di Gugus IV Kecamatan 
Gerokgak tahun pelajaran 2017/2018. Jadi dapat disimpulkan penerapan model pembelajaran kooperatif tipe Student Facilitator And Explaining (SFAE) berbasis Tri Kaya Parisudha berpengaruh terhadap hasil belajar antara siswa pada siswa kelas III semester II di Gugus IV Kecamatan Gerokgak tahun pelajaran 2017/2018. Bagi Siswa

Adapun saran yang dapat disampaikan antara lain 1) bagi siswa Diterapkannnya model pembelajaran Student Facilitatot and Eksplaining yang melibatkan siswa secara aktif dalam proses pembelajaran dan belajar yang menyenangkan sehingga dapat mengembangkan pemahaman dan mendapatkan pengetahuan baru melalui pengalaman yang ditemukan sendiri. 2) Bagi Guru, Guru dapat menggunakan model pembelajaran Student Facilitatot and Eksplaining sebagai salah satu alternatif dalam pembelajaran matematika karena dapat mengembangkan kreativitas dalam pembelajaran dengan mengkaitkan kehidupan sehari-hari dalam pembelajaran, sehingga keaktifan siswa dapat lebih baik. 3) Bagi Kepala Sekolah Kepala Sekolah dapat dijadikan sebagai dalam mengambil kebijakan untuk meningkatkan kualitas pendidikan di sekolah serta memberikan informasi dan memfasilitasi para guru agar mampu menggunakan model pembelajaran yang lebih inovatif. 4) Bagi peneliti lain agar hasil penelitian ini dapat digunakan sebagai salah satu acuan kepustakaan untuk melaksanakan penelitian dalam variabel yang sama ataupun variabel berbeda.

\section{Daftar Rujukan}

Agung, A. A. G. (2014). Buku Ajar Metodologi Penelitian Pendidikan. Malang: Aditya Media Publishing. Ariska, J. (2017). Pengaruh Model Pembelajaran Student Facilitator And Explaining Terhadap Hasil Belajar Menggambar Busana Di Smk N 1 Depok. Jurnal Pendidikan Teknik Busana UNY.

Dharma, I. K. S. (2016). Penerapan model pembelajaran think talk write (Student Facilitator And Explaining (SFAE) Berbasis Tri Kaya Parisudha) berbantuan media konkret untuk meningkatkan Hasil belajar matematika. Mimbar PGSD Universitas Pendidikan Ganesha, 4(1).

Fauzi, Riski, D. (2016). Pengaruh Model Pembelajaran SFAEBermediakan Mind Mapping Terhadap Hasil Belajar Matematika Siswa". Mimbar PGSD Universitas Pendidikan Ganesha, 4(1).

Mudarini, H. (2017). (2017). Pengaruh Model Pembelajaran Student Facilitator and Explaining (SFAE) Berbantuan Media Kartu Terhadap Hasil Belajar IPA. E-Journal PGSD Undiksha, 5(2).

Ngalimun. (2014). Strategi dan Model Pembelajaran. Yogyakarta: Aswaja Pressindo.

Santa, P. K. M. A. \& Made Suarjana. \& I. Gde Wawan Sudatha. (2013). Pengaruh Model Pembelajaran Student Facilitator And Explaining Terhadap Prestasi Belajar Matematika Siswa Kelas V Semester II SD Negeri 2 Gianyar. Mimbar PGSD Universitas Pendidikan Ganesha, 1(1).

Seandanu, R. (2017). Pengaruh Metode Student Facilitator And Explaining Terhadap Pemahaman Bahaya Narkoba Pada Siswa Kelas X Smk Pgri 4 Kediri Tahun Ajaran 2016/2017. Jurnal Simki-Pedagogia, 1(2).

Sukadi; Dkk. (2007). Belajar dan Pembelajaran (Berorientasi Konten Kearifan Lokal Budaya Bali). Singaraja: Undiksha Press.

Susanto, A. (2015). Teori Belajar dan Pembelajaran di Sekolah Dasar. Jakarta: Prenadamedia Grup.

Trianto. (2010). Mendesain Model Pembelajaran Inovatif-Progresif: Konsep Landasan, dan Implementasinya Pada Kurikulum Tingkat Satuan Pendidikan (KTSP). Jakarta: Kencana Predana Media Grup.

Yanto, Y. (2018). Penerapan Model Pembelajaran Kooperatif Tipe Student Facilitator and Explaining Terhadap Hasil Belajar Matematika Siswa. Jurnal Pendidikan Matematika, 1(1). 